\title{
Optimization of selected plant growth regulators on callus induction of Oryza sativa L. var MR 219
}

\author{
${ }^{1}$ Siti Nur Adila, H. and ${ }^{1,2, *}$ Nor Azma, Y. \\ ${ }^{1}$ Faculty of Plantation and Agrotechnology, Universiti Teknologi MARA Cawangan Melaka, Kampus Jasin \\ 77300, Merlimau Melaka, Malaysia \\ ${ }^{2}$ Agricultural Biotechnology Research Interest Group (RIG), Faculty of Plantation and Agrotechnology, \\ Universiti Teknologi MARA Cawangan Melaka, Kampus Jasin 77300, Merlimau Melaka, Malaysia
}

\section{Article history:}

Received: 18 April 2021

Received in revised form: 30

September 2021

Accepted: 4 November 2021

Available Online: 26

November 2021

Keywords:

Rice,

MR219,

Callus,

Tissue culture,

Micropropagation

DOI:

https://doi.org/10.26656/fr.2017.5(S4).011

\begin{abstract}
MR 219, an indica rice from a cross between MR 137 and MR 151 is a long-grain rice variety of high-yielding, good quality of shape and taste, short maturation as well as resistance to blast and bacterial leaf blight. However, it is regarded as a recalcitrant variety due to its low ratio of callogenesis and regeneration in in vitro culturing. This would be a hindrance to crop improvements such as genetic transformation and other crop improvement methods. The objective of this study was to optimize the concentrations and combinations of plant growth regulators (PGRs) which were 2,4-Dichlorophenoxyacetic acid (2,4-D), Kinetin (KIN) and Naphthalene acetic acid (NAA) on its callus induction that ranging from 0.5 to $15.0 \mathrm{mg} / \mathrm{L}$. The callus was induced from the mature seeds of MR 219 on the Murashige and Skoog (MS) media supplemented with $4.4 \mathrm{~g} / \mathrm{L}$ of MS powder with vitamins, $30.0 \mathrm{~g} / \mathrm{L}$ of sucrose and $3.5 \mathrm{~g} / \mathrm{L}$ of gelrite with the addition of 2,4-D, KIN and NAA in different concentrations and combinations. All media supplemented with 2,4$\mathrm{D}$ had successfully induced the callus and $2.0 \mathrm{mg} / \mathrm{L}$ of $2,4-\mathrm{D}$ was the best concentration for the callus induction with a $100 \%$ success rate. The addition of $15.0 \mathrm{mg} / \mathrm{L}$ of NAA, provided less time taken for callus induction with better callus morphology which resulted in fewer browning problems.
\end{abstract}

\section{Introduction}

Oryza sativa L. or known as Asian rice is the primary food grain and a major source of food that is consumed as a staple food by almost half of the world's population especially in Asian countries including Malaysia (Sankepally et al., 2016; Firdaus et al., 2020). MR 219 is one of the rice varieties that offers many agricultural advantages such as a high yield and suitable quality in shape as well as good taste (Radziah et al., 2012). It is the most common rice variety commercially cultivated in Malaysia and one of the main varieties applied in Malaysian granary areas. Its single grain can weigh as much as $28.0-30.0 \mathrm{mg}$ while the number of grains can be up to 200 which are higher than the weight and number of grains of previously released varieties. It also has strong culms and is resistant to blast and bacterial leaf blight. Besides, this variety also has early maturation with a short life cycle of 105-111 days.

Despite all these benefits, this rice cultivar is regarded as a recalcitrant variety in in vitro tissue culture in terms of the capability of producing callus (Abiri et al., 2017). Recalcitrance is one of the problems for crop improvement, mostly in monocotyledonous species (Artadana et al., 2017). Low rice improvement percentage would be achieved if it is done through the conventional approach as it will be limited by the natural incompatibilities and consuming a lot of time, thus there is a vital need to use in vitro approaches for improvement of the crop (Shilpy et al., 2018). Although a lot of protocols have been reported for MR 219 micropropagation, the recalcitrance of this indica rice is higher compared to the japonica subspecies. The ability to produce callus is essential for rice improvement through a biotechnological approach and it is described as one of the prime steps in crop plants to be manipulated by biotechnological means (Manoharan et al., 2020). The suitable hormones with the appropriate ratio of concentration can successfully stimulate the proliferation and differentiation of rice callus (Tang et al., 2017).

Through this technique, it provided information on 
rapid rice callus inducement which is to be used in platforms for genetically modified callus, propagation, regeneration or transgenic development. According to Ijaz et al. (2019), the transformation of genetic for most of the indica rice cultivars is hindered by the poor performance of in vitro culture and low potential of regeneration. Therefore, the quality improvement of MR 219 in terms of callogenesis should be done as well as the utilization of its secondary metabolites through callus culture into valuable products like pharmaceutical, nutraceutical and cosmeceutical products. The extraction by-products through this method will be more stabilized, consistent and sterilized under a controlled environment and obtained in a short period. Hence, a study was conducted to optimise the callus induction protocol of MR 219 through the optimization of the concentrations and combinations of 2,4-D, KIN and NAA for its utilization in tissue culture-based crop improvement programmes.

\section{Materials and methods}

\subsection{Plant materials and experimental location}

This research work was carried out at Tissue Culture Laboratory, Faculty of Plantation and Agrotechnology, Universiti Teknologi MARA, Jasin Campus. The dehusked seeds of mature grain from MR 219 (Malaysian Rice 219) were obtained from the rice germplasm collection, Malaysian Agricultural Research and Development Institute (MARDI) Seberang Perai.

\subsection{Seed surface sterilization}

The manually dehusked mature rice seeds were surface-sterilized using absolute ethanol for 2 mins. Afterwards, the seeds were further sterilized using a mixture of $50 \%$ Clorox (sodium hypochlorite 5.99\%) with four drops of Tween-20, shaken on a vortex mixer for 30 mins. After surface sterilization, the dehusked seeds were rinsed 5 times with sterile distilled water and blot dried on sterilized $90 \mathrm{~mm}$ filter paper (Radziah et al., 2012).

\subsection{Seed inoculation and callus induction}

The sterilized seeds were then inoculated onto solid MS medium with $4.4 \mathrm{~g} / \mathrm{L}$ of MS powder with vitamins, $30.0 \mathrm{~g} / \mathrm{L}$ of sucrose, $3.5 \mathrm{~g} / \mathrm{L}$ of gelrite supplemented with different concentrations and combinations of 2,4-D (0.5 $-2.0 \mathrm{mg} / \mathrm{L}), \mathrm{NAA}(1.0-2.0 \mathrm{mg} / \mathrm{L}$ and $5.0-15.0 \mathrm{mg} / \mathrm{L})$ and $\mathrm{KIN}(0.5-1.5 \mathrm{mg} / \mathrm{L})$ (Table 1). An experimental unit of five sterile seeds was cultured on a sterile petri dish $(100 \times 15 \mathrm{~mm})$ for each treatment with three replicates containing $20 \mathrm{~mL}$ of callus induction medium. These were then cultured under 16/8 hours (light/dark) photoperiod conditions in the growth chamber of $26 \pm 2^{\circ} \mathrm{C}$ under the light of 2000 lux white fluorescent tubes for four weeks.

Table 1. Treatments and PGR concentrations and combination used in this study.

\begin{tabular}{cccc}
\hline \multirow{2}{*}{ Treatment } & \multicolumn{3}{c}{ PGR Concentration (mg/L) } \\
\cline { 2 - 4 } & KIN & $2,4-\mathrm{D}$ & NAA \\
\hline Control & 0.0 & 0.0 & 0.0 \\
1 & 0.0 & 1.0 & - \\
2 & 0.0 & 1.5 & - \\
3 & 0.0 & 2.0 & - \\
4 & 0.5 & 1.0 & - \\
5 & 0.5 & 1.5 & - \\
6 & 0.5 & 2.0 & - \\
7 & 1.0 & 1.0 & - \\
8 & 1.0 & 1.5 & - \\
9 & 1.0 & 2.0 & - \\
10 & 1.5 & 1.0 & - \\
11 & 1.5 & 1.5 & - \\
12 & 1.5 & 2.0 & - \\
13 & - & 0.5 & - \\
14 & - & 0.5 & 5.0 \\
15 & - & 0.5 & 10.0 \\
16 & - & 0.5 & 15.0 \\
17 & - & 1.0 & 5.0 \\
18 & - & 1.0 & 10.0 \\
19 & - & 1.0 & 15.0 \\
20 & - & 1.5 & 5.0 \\
21 & - & 1.5 & 10.0 \\
22 & - & 1.5 & 15.0 \\
\hline
\end{tabular}

The effect of PGRs on the callus induction, biomass and other morphological responses such as colour and shapes were observed and recorded on weekly basis for four weeks. The percentage of callus induction was calculated based on the percentage of explants capable of being developed into the callus considering that each callus piece originated from a single seed. The biomass data were taken in terms of fresh weight (FW) of callus after four weeks. The seeds were removed and the harvested callus was weighed individually on an electrical balance. Then, the callus was dried in a ventilating oven till a constant weight and the dry weight (DW) were recorded (Huang and Liu, 2002; Reddy et al., 2013). As for the morphological responses measured which were the colour and shape of induced callus, the colour of callus was categorized according to Figure 1 which was rated as $1=$ white, $2=$ creamy whitish, $3=$ creamy, $4=$ light yellow, $5=$ yellowish, $6=$ light brown, $7=$ brown and $8=$ dark brown (Wanichananan et al., 2010). The callus was photographed with the camera of Nikon D3100 DSLR 18-55 mm.

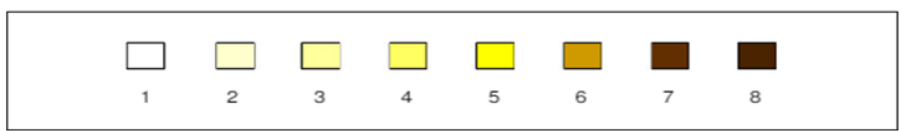

Figure 1. Colour chart of callus (Wanichananan et al., 2010). 


\subsection{Experimental design and statistical analysis}

Each treatment was replicated thrice in a completely randomized block design (CRD) and contained five experimental units. Data were analysed using one way of analysis of variance (ANOVA) and the Tukey Test of the Statistical Package for Social Science (SPSS).

\section{Results and discussion}

3.1 Effect of different PGRs on callus induction and rooty or/and shooty callus

In vitro callus induction was studied from the mature seeds of MR 219 by using MS medium with different concentrations and a combination of KIN, 2,4-D and NAA. The effects of these phytohormones on the induced callus were observed. The study showed that a combination of 2,4-D with other PGRs or the use of 2,4D alone could stimulate callus formation compared to control. Treatment with no phytohormones supplemented into the MS medium was tested as a control. Control had no callus formation but only produced plantlets. According to Vikrant and Rashid (2003), 2,4-D was considered a reliable growth regulator for somatic embryogenesis induction. Besides, the application of 2,4$\mathrm{D}$ alone recorded the highest percentage of callus induction which was achieved by T3 $(2.0 \mathrm{mg} / \mathrm{L} 2,4-\mathrm{D})$ in Figure 2.

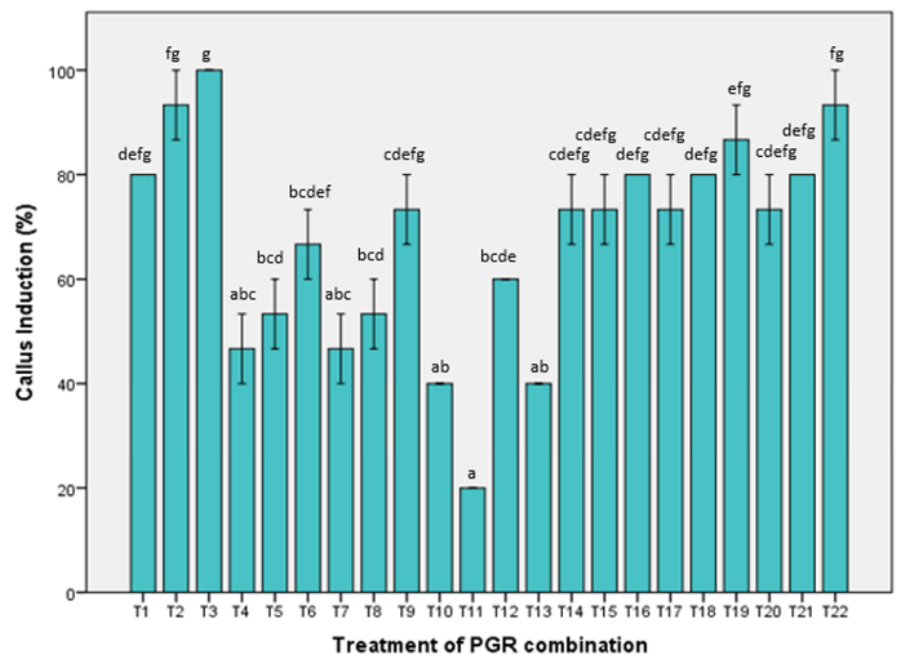

Figure 2. Effect of different PGRs on the callus induction. Columns indicate means for replicates with error bars showing standard errors. Column with the same superscript are not significantly different at $1 \%$ level $(\mathrm{p}<0.01)$ and $5 \%$ level $(\mathrm{p}<0.05)$.

This result was in agreement with previous researchers that application of 2,4-D alone gave a better result for induction of callus compared to combinations with other auxins and cytokinins (Shahsavari et al., 2010; Zhao et al., 2011). Rahman et al. (2007) described that 2,4-D had the capability to remove actin and slow down the cytoplasmatic streaming. Most previous reports such as Shahsavari et al. (2010), Libin (2012), Upadhyaya et al. (2015) and Abiri et. al. (2017) recommended 1.5 to $2.0 \mathrm{mg} / \mathrm{L}$ of $2,4-\mathrm{D}$ alone to be used in rice callus induction. Out of all different concentrations of 2,4-D tested in this study, $2.0 \mathrm{mg} / \mathrm{L}$ of 2,4-D (T3) was recorded to be the most effective in inducing callus with $100.00 \pm 0.00 \%$ whereas the lowest percentage was recorded with the concentration of 0.5 $\mathrm{mg} / \mathrm{L}$ of $2,4-\mathrm{D}$ (T13) with $40.00 \pm 0.00 \%$. This might be due to the low concentration of 2,4-D to promote better callus induction of MR 219.

Meanwhile, for the MS medium treated with 2,4-D and NAA, there was a production of callus accompanied by other organ formations such as shoots and roots. Although different levels of growth hormone did not give significantly different effects on the number of shoots and roots produced, the highest was recorded in $\mathrm{T} 16$ (0.5 mg/L 2,4-D and $15.0 \mathrm{mg} / \mathrm{L}$ NAA) and T17 (1.0 $\mathrm{mg} / \mathrm{L} 2,4-\mathrm{D}$ and $5.0 \mathrm{mg} / \mathrm{L}$ NAA) with $93.33 \pm 11.55 \%$ whereas the lowest was recorded by T3 $(2.0 \mathrm{mg} / \mathrm{L} 2,4-\mathrm{D})$ with $46.67 \pm 11.55 \%$ (Figure 3 ). The result was in agreement with previous reports that showed a low level of 2,4-D which was below and the same concentration of $1 \mathrm{mg} / \mathrm{L}$, the explants were growing the roots and shoots rather than callus (Lee et al., 2002; Radziah et al., 2012).

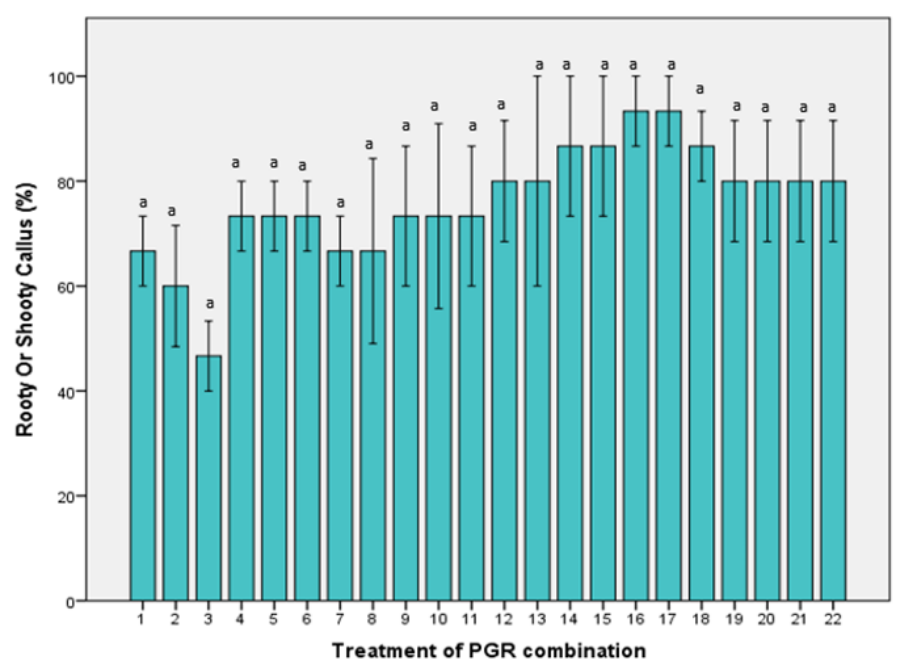

Figure 3. Effect of different PGRs on the rooty or/and shooty callus. Columns indicate means for replicates with error bars showing standard errors. Column with the same superscript are not significantly different at $1 \%$ level $(\mathrm{p}<0.01)$ and $5 \%$ level $(\mathrm{p}<0.05)$.

Low concentration of 2,4-D such as $0.5 \mathrm{mg} / \mathrm{L}$ resulted in a higher percentage of rooty and shooty callus with $80 \pm 34.64 \%$ compared to a higher concentration of 2,4-D regardless of what concentration and combination of other PGRs. Besides, for the combination of KIN and 2,4-D, it resulted in a greater amount of shooty callus. Similar results were observed by Arunyanart and 
Chaitrayagun (2005) where, for low auxin/cytokinin ratio, KIN and 2,4-D prompted root induction.

\subsection{Effect of different PGRs on callus biomass}

The highest FW (Figure 4) was recorded by T22 (1.5 $\mathrm{mg} / \mathrm{L} \mathrm{2,4-D} \mathrm{and} 15.0 \mathrm{mg} / \mathrm{L}$ NAA) which was significantly different from all the treatments in affecting the FW of the induced callus. This showed that both 2,4$\mathrm{D}$ and NAA increased FW and this combination was more effective than 2,4-D, NAA or KIN alone or a combination of 2,4-D and KIN on callus biomass. As cited from Suraiya and Alina (2018), the combination of different types of auxins was a better alternative compared to the use of single auxin as described in the research done in selected rice varieties in MS medium supplemented with 2,4-D and NAA. For DW, all the treatments were not significantly different from each other. This also had been shown in the results of Abiri et al. (2017), that the use of 2,4-D alone was not suitable to proliferate and increase callus biomass.

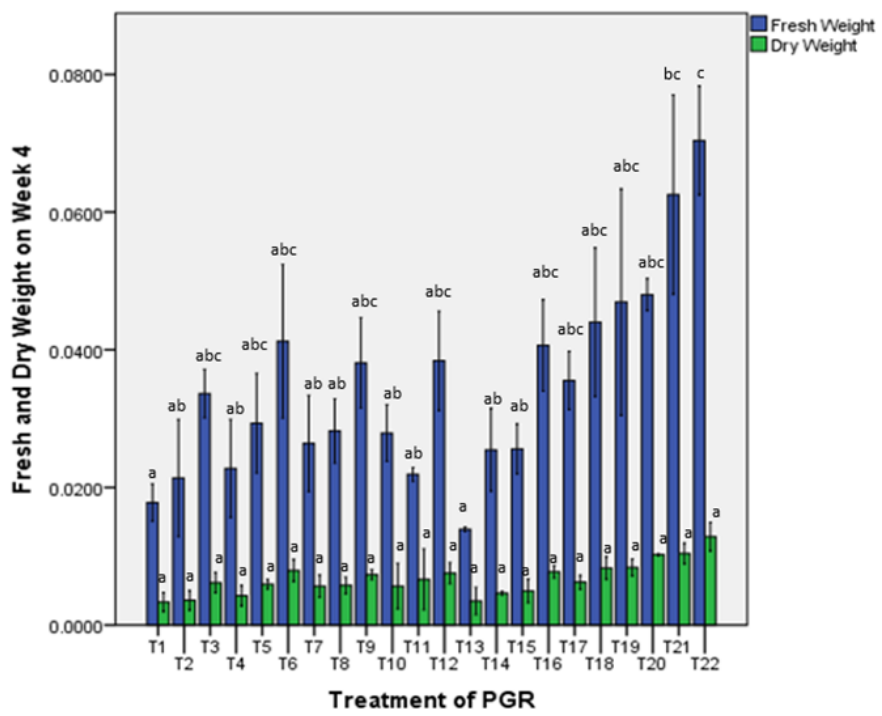

Figure 4. Effect of different PGRs on the FW and DW on week 4. Columns indicate means for replicates with error bars showing standard errors. Columns with the same superscript within each category are not significantly different at $1 \%$ level $(\mathrm{p}<0.01)$ and $5 \%$ level $(\mathrm{p}<0.05)$.

T22 (1.5 mg/L 2,4-D + $15.0 \mathrm{mg} / \mathrm{L}$ NAA $)$ showed the highest FW and DW which were $0.0704 \pm 0.0137 \mathrm{~g}$ and $0.0128 \pm 0.0036 \mathrm{~g}$ respectively. These results appeared to be the most effective hormone combinations on the growth of callus biomass (FW and DW) compared to other combinations of 2,4-D and NAA treatments. The lowest value of FW and DW were $0.0139 \pm 0.0006 \mathrm{~g}$ and $0.0035 \pm 0.0034 \mathrm{~g}$ by T13 $(0.5 \mathrm{mg} / \mathrm{L} 2,4-\mathrm{D})$ followed by T1 $(1.0 \mathrm{mg} / \mathrm{L}$ 2,4-D). These treatments were not significantly different from each other. However, as the concentrations of KIN and 2,4-D got higher than $1.5 \mathrm{mg} /$ $\mathrm{L}$, the FW and DW were increased. This result was in agreement with Abiri et al. (2017) which showed that the combination of cytokines with auxins was effective in the callus's induction and proliferation of MR 219.

\subsection{Effect of different PGRs on days for callus induction}

For this purpose, the observation was done daily and any formation of the callus was recorded. MS medium supplemented with 2,4-D and KIN showed the earliest signs of callus formation. Within one week, swelling of the scutellum and mass formation on the surface within the scutellum region of the seed was observed.

As shown in Figure 5, T6 $(0.5 \mathrm{mg} / \mathrm{L} \mathrm{KIN} \mathrm{and} 2.0$ $\mathrm{mg} / \mathrm{L} 2,4-\mathrm{D})$ had the earliest days to callus induction which took 5 days followed by T5 $(0.5 \mathrm{mg} / \mathrm{L} \mathrm{KIN} \mathrm{and}$ $1.5 \mathrm{mg} / \mathrm{L} 2,4-\mathrm{D})$ which was 9 days. These two treatments had a high concentration of 2,4-D and a low concentration of KIN. For media containing 2,4-D and NAA, the earliest days to callus induction was on day 10 which was by T21 (1.5 mg/L 2,4-D and $10.0 \mathrm{mg} / \mathrm{L}$ NAA). In addition, the treatment that had only 2,4-D which was T13 $(0.5 \mathrm{mg} / \mathrm{L}$ 2,4-D) took the longest days to have visible callus induction which took 18 days. Through this study, treatments of 2,4-D and KIN showed the earliest signs of callus formation followed by treatments of 2,4-D and NAA then finally by treatments of 2,4-D alone.

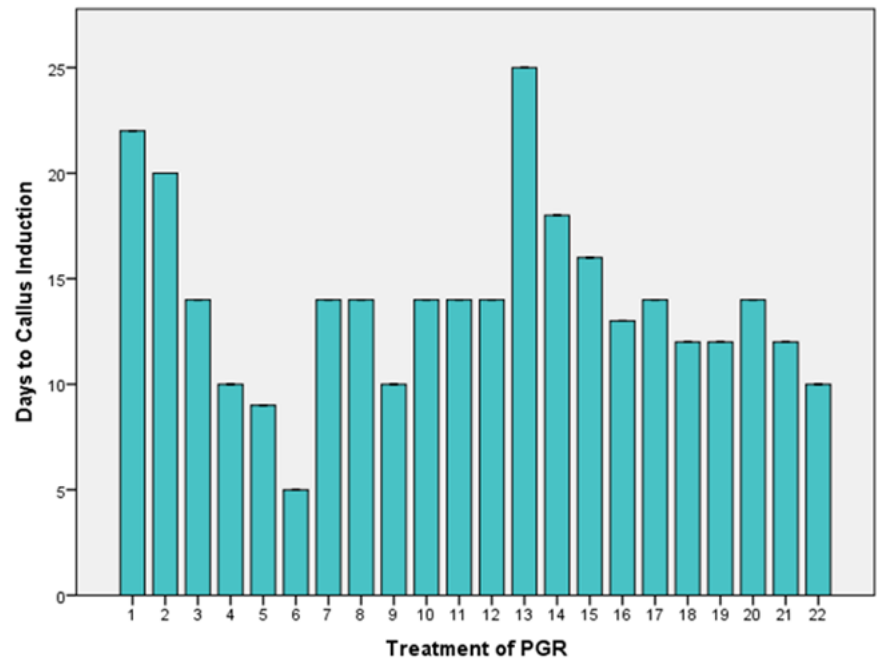

Figure 5. Effect of different PGRs on days to callus induction.

The result of 2,4-D as auxin combined with cytokinins showed the earliest callus induction was in agreement with Al-Hussaini et al. (2015) that described 2,4-D as auxin combined with Benzyl adenine (BA) as cytokinins took less time to induce potato callus compared to media supplemented with NAA and cytokinins. This may be due to $2,4-\mathrm{D}$ being more efficiently influenced on cell enlargement and cell divisions compared to other growth regulators. Besides, according to Abiri et al. (2017), cytokinins such as KIN and 6-Benzylaminopurine (BAP) were better callus regeneration enhancers of MR 219 compared to Zeatin or Thidiazuron (TDZ) combinations which resulted in no 
callus regeneration. Furthermore, Azizi et al. (2015) also found that KIN had the best efficiency compared with other cytokinin concentrations in different indica rice varieties such as MRQ 50, MR 269, MR 276, MR 219, MR Q74 and MR 84.

\subsection{Effect of different PGRs on morphology}

The callus can be distinguished based on morphological characteristics. A healthy culture was indicated by rapid growth and a light colour callus while a friable callus of crumbly appearance which was easy to break up makes it suitable for sub-culturing or suspension culture (Trigiano and Gray, 2005). As all the treatments involved the combination with 2,4-D or 2,4-D alone (Table 2), there were fewer green spots recorded on the callus. This was because 2,4-D had an inhibitory impact on chlorophyll formation which may be resulted in the whitish or yellowish callus (Shukla et al. 2014).

In addition, the greening of the callus was related to the ability of plant generation. They were especially observed in the media supplemented with KIN. According to Suraiya and Alina (2018), increasing the concentration of KIN in selected indica rice was found to significantly increase the percentage of plant regeneration. The green spots which then would be further developed into numbers of shoots would turn into plants. Besides, Zuraida et al. (2011) also described that Malaysian MR219 embryogenic callus appearance was dry, compact, light yellowish and nodular. And in this study, as compared to $2 \mathrm{mg} / \mathrm{L}$ of $2,4-\mathrm{D}$, the callus produced was friable, nodular, dry and rather regular in size. Furthermore, the callus induced from a low concentration of 2,4-D exhibited watery and browning conditions such as shown in T1, T2 and T13 which had concentrations of $2,4-\mathrm{D}$ of $1.0,1.5$ and $0.5 \mathrm{mg} / \mathrm{L}$ respectively.

Callus grown on media with the combination of 2,4D and NAA showed faster growth compared to other cultures. Moreover, the callus on these media produced less browning callus compared to those treated with 2,4D alone and a combination of 2,4-D and KIN. The qualities of callus produced had desired features which were creamy, globular and big. The use of 2,4-D alone would have better callus induction, but such callus would suffer from browning. The was because of the addition of NAA that essentially overcame this callus browning. This was in agreement with Rahman et al. (2015), for MRQ 80 and MRQ 50 with the combination of 1.0 and $5.0 \mathrm{mg} / \mathrm{l}$ of 2,4-D and 5.0 and $10.0 \mathrm{mg} / \mathrm{l}$ of NAA did not detect any browning incidence. Auxin such as NAA enhanced putrescine biosynthesis which increased the putrescine/spermidine ratio which then controlled the genetical callus browning trait.
Through visual observation, embryonic, shooty or rooty callus can be classified as the callus with some organ regeneration whereas callus without any obvious organ regeneration is compact or friable callus (Ikeuchi et al., 2013). Based on research by Abiri et al. (2017), the colour of the callus can be a suitable selection criterion in classifying the embryogenic callus. The embryogenic indica rice callus was characterized as pale yellow-white with a loose friable texture in appearance while for non-embryogenic callus, a white, rough and pointed callus was observed which were shown in Table 2.

Table 2. Induction of callus and their morphological characteristics.

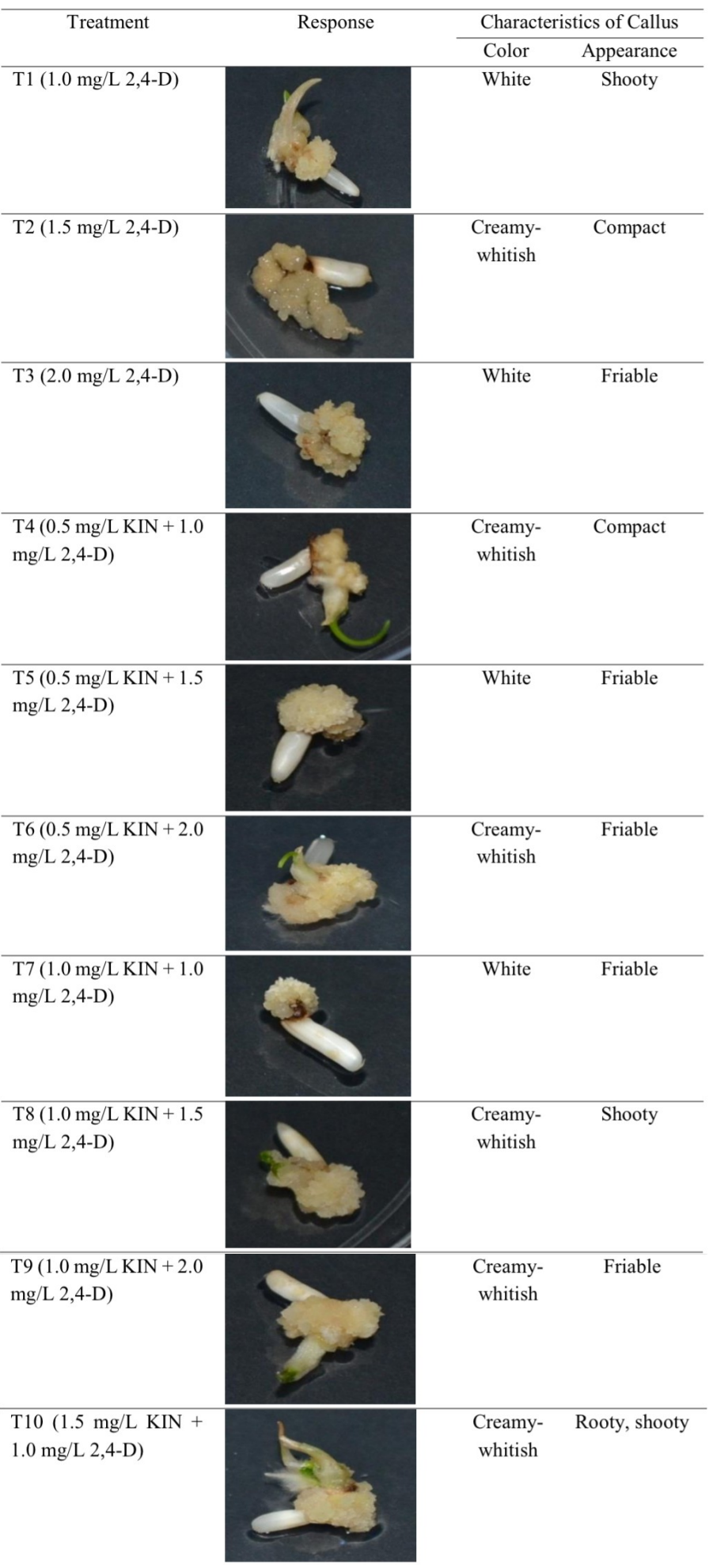


Table 2 (Cont.). Induction of callus and their morphological characteristics.

\begin{tabular}{|c|c|c|c|}
\hline \multirow{2}{*}{ Treatment } & \multirow{2}{*}{ Response } & \multicolumn{2}{|c|}{ Characteristics of Callus } \\
\hline & & Color & Appearance \\
\hline $\begin{array}{l}\text { T11 (1.5 mg/L KIN + } \\
1.5 \mathrm{mg} / \mathrm{L} 2,4-\mathrm{D})\end{array}$ & & $\begin{array}{l}\text { Creamy- } \\
\text { whitish }\end{array}$ & Compact \\
\hline $\begin{array}{l}\text { T12 (1.5 mg/L KIN + } \\
2.0 \mathrm{mg} / \mathrm{L} 2,4-\mathrm{D})\end{array}$ & & $\begin{array}{l}\text { Creamy- } \\
\text { whitish }\end{array}$ & Friable \\
\hline T13 (0.5 mg/L 2,4-D) & & $\begin{array}{l}\text { Creamy- } \\
\text { whitish }\end{array}$ & Compact \\
\hline $\begin{array}{l}\text { T14 (0.5 mg/L 2,4-D + } \\
5.0 \mathrm{mg} / \mathrm{L} \mathrm{NAA})\end{array}$ & & $\begin{array}{l}\text { Creamy- } \\
\text { whitish }\end{array}$ & Embryonic \\
\hline $\begin{array}{l}\text { T15 ( } 0.5 \mathrm{mg} / \mathrm{L} 2,4-\mathrm{D}+ \\
10.0 \mathrm{mg} / \mathrm{L} \text { NAA })\end{array}$ & & $\begin{array}{l}\text { Creamy- } \\
\text { whitish }\end{array}$ & Shooty \\
\hline $\begin{array}{l}\text { T16 (0.5 mg/L 2,4-D + } \\
15.0 \mathrm{mg} / \mathrm{L} \mathrm{NAA})\end{array}$ & & $\begin{array}{l}\text { Creamy- } \\
\text { whitish }\end{array}$ & Shooty, rooty \\
\hline $\begin{array}{l}\mathrm{T} 17(1.0 \mathrm{mg} / \mathrm{L} 2,4-\mathrm{D}+ \\
5.0 \mathrm{mg} / \mathrm{L} \mathrm{NAA})\end{array}$ & & $\begin{array}{l}\text { Creamy- } \\
\text { whitish }\end{array}$ & Rooty \\
\hline $\begin{array}{l}\text { T18 (1.0 mg/L } 2,4-\mathrm{D}+ \\
10.0 \mathrm{mg} / \mathrm{L} \mathrm{NAA})\end{array}$ & & $\begin{array}{l}\text { Creamy- } \\
\text { whitish }\end{array}$ & Shooty, rooty \\
\hline $\begin{array}{l}\mathrm{T} 19(1.0 \mathrm{mg} / \mathrm{L} 2,4-\mathrm{D}+ \\
15.0 \mathrm{mg} / \mathrm{L} \mathrm{NAA})\end{array}$ & & $\begin{array}{l}\text { Creamy- } \\
\text { whitish }\end{array}$ & Shooty \\
\hline $\begin{array}{l}\text { T20 (1.5 mg/L } 2,4-\mathrm{D}+ \\
5.0 \mathrm{mg} / \mathrm{L} \mathrm{NAA})\end{array}$ & & $\begin{array}{l}\text { Creamy- } \\
\text { whitish }\end{array}$ & Shooty \\
\hline $\begin{array}{l}\text { T21 (1.5 mg/L 2,4-D + } \\
10.0 \mathrm{mg} / \mathrm{L} \mathrm{NAA})\end{array}$ & & $\begin{array}{l}\text { Creamy- } \\
\text { whitish }\end{array}$ & Friable \\
\hline $\begin{array}{l}\text { T22 (1.5 mg/L 2,4-D + } \\
15.0 \mathrm{mg} / \mathrm{L} \mathrm{NAA})\end{array}$ & & $\begin{array}{l}\text { Creamy- } \\
\text { whitish }\end{array}$ & Rooty, shooty \\
\hline
\end{tabular}

\section{Conclusion}

There were number of restrictive factors regarding the micro-propagation of indica rice including MR219. In spite of being Malaysian hybrid rice that had high yield, good taste and shape quality, it was considered as a recalcitrant cultivar to be cultured in vitro if the highefficiency protocol was not being determined and conducted. Therefore, to achieve a high-efficiency protocol based on MR 219's requirements, it is advisable to do assessments on specific factors separately. From this study, a successful protocol for callus induction was achieved for MR 219 rice variety. It can be concluded that different types, combinations and concentrations of PGRs which were 2,4-D, KIN and NAA affected the callus induction. This study had established that MS media supplemented with $4.4 \mathrm{~g} / \mathrm{L}$ of MS powder with vitamins, $30 \mathrm{~g} / \mathrm{L}$ of sucrose and $3.5 \mathrm{~g} / \mathrm{L}$ of gelrite with an addition of $2.0 \mathrm{mg} / \mathrm{L}$ of $2,4-\mathrm{D}$ was the optimal medium for callus induction and with the addition of $15.0 \mathrm{mg} / \mathrm{L}$ of NAA, it provided less time taken for callus induction with better callus morphology with less browning problems. Besides, the combination of auxin-auxin or auxin alone could induce callus for MR 219 compared to auxin-cytokinin combination that led to no callus induction. In order to achieve a high-efficiency protocol for indica rice especially for Malaysian rice, there must be an optimization of in vitro culture conditions alongside improved tissue culture protocol.

\section{Conflict of interest}

The authors declare no conflicts of interest.

\section{Acknowledgement}

The authors acknowledge the financial supported by UiTM (600-IRMI 5/3/GIP (015/2019), facilities provided by the Faculty of Plantation and Agrotechnology, UiTM and mature seeds provided by Malaysian Agricultural Research and Development Institute (MARDI).

\section{References}

Abiri, R., Maziah, M., Shaharuddin, N.A., Yusof, Z.N.B., Atabaki, N., Hanafi, M.M. and Valdiani, A. (2017). Enhancing somatic embryogenesis of Malaysian rice cultivar MR 219 using adjuvant materials in a high-efficiency protocol. International Journal of Environmental Science and Technology, 14(5), 1091-1108. https://doi.org/10.1007/s13762016-1221-y

Al-Hussaini, Z.A., Yousif, S.H.A. and Al-Ajeely, S.A. (2015). Effect of different medium on callus induction and regeneration in potato cultivars. 
International Journal of Current Microbiology and Applied Sciences, 4(5), 856-865.

Artadana, I.B.M., Suhono, G.B.F., Hardjo, P.H., Purwanto, M., Wang, Y.B. and Supaibulwattana, K. (2017). Plant regeneration induced from mature Embryo-derived callus of Balinese red rice (Oryza sativa Cv. Barak Cenana). Bali Medical Journal, 6, S12-S17. https://doi.org/10.15562/bmj.v6i3.710

Arunyanart, S. and Chaitrayagun, M. (2005). Induction of somatic embryogenesis in lotus (Nelumbo nucifera Geartn). Scientia Horticulturae, 105(3), 411 -420. https://doi.org/10.1016/j.scienta.2005.01.034

Azizi, P., Rafii, M.Y., Mahmood, M., Hanafi, M.M., Abdullah, S.N.A., Abiri, R. and Sahebi, M. (2015). Highly efficient protocol for callogenesis, somagenesis and regeneration of indica rice plants. Comptes Rendus - Biologies, 338(7), 463-470. https://doi.org/10.1016/j.crvi.2015.04.004

Firdaus, R.R.B., Tan, M.L., Rahmat, S.R. and Gunaratne, M.S. (2020). Paddy, rice and food security in Malaysia: A review of climate change impacts. Cogent Social Sciences, 6(1), 1818373. https:// doi.org/10.1080/23311886.2020.1818373

Huang, W.L. and Liu, L.F. (2002). Carbohydrate metabolism in rice during callus induction and shoot regeneration induced by osmotic stress. Botanical Bulletin of Academia Sinica, 43, 107-113.

Ijaz, B., Sudiro, C., Hyder, M.Z., Malik, S.M., Farrakh, S., Schiavo, F.L. and Yasmin, T. (2019). Histomorphological analysis of rice callus cultures reveals differential regeneration response with varying media combinations. In Vitro Cellular and Developmental Biology - Plant, 55, 569-580. https:// doi.org/10.1007/s11627-019-09974-6

Ikeuchi, M., Sugimoto, K. and Iwase, A. (2013). Plant callus: mechanisms of induction and repression. The Plant Cell, 25(9), 3159-3173. https:// doi.org/10.1105/tpc.113.116053

Lee, K.S., Jeon, H.S. and Kim, M.Y. (2002). Optimization of a mature embryo based in vitro culture system for high-frequency somatic embryogenic callus induction and plant regeneration from japonica rice cultivars. Plant Cell Tissue Organ Culture, 71, 237-244.

Libin, A. (2012). Callus induction and plant regeneration of Sarawak rice (Oryza sativa L.) variety Biris. African Journal of Agricultural Research, 7(10), 5897. https://doi.org/10.5897/AJAR12.587

Manoharan, A., Gurusamy, A., Chocklingam, V., Elangovan, S., Krishnamoorthi, A. and Krishnan, A. (2020). Response for Callus Induction in Popular Indica Rice Varieties and Its Mutant Lines Using
Different Media Combinations. Biosciences Biotechnology Research Asia, 17(2), 407-412. https://doi.org/10.13005/bbra/2844

Radziah, C.M.Z., Siti Nurkhalida, A.K., Zamri, Z. and Ismanizan, I. (2012). Effect of illumination, casein hydrolysate and proline on callus induction of Oryza sativa L. cv. MR 219. Malaysian Applied Biology, 41(1), 37-41.

Rahman, A., Bannigan, A., Sulaman, W., Pechter, P., Blancaflor, E.B., Baskin, T.I. (2007). Auxin, actin and growth of the Arabidopsis thaliana primary root. Plant Journal, 50(3), 514-528. https:// doi.org/10.1111/j.1365-313X.2007.03068.x

Rahman, Z.A., Ramli, A., Hosni, H., Kamaruzaman, R., Seman, Z.A., Othman, A.N., Zainal, Z. and Uddain, J. (2015). Efficient plant regeneration of Malaysian aromatic rice (Oryza sativa L.) via improved somatic embryogenesis pathway. Emirates Journal of Food and Agriculture, 27(11), 857-863. https:// doi.org/10.9755/ejfa.2015-07-535

Reddy, N.V., Ghosh, S.B., Chandramouli, K., Vijaya, T., Pushpalatha, B., Anitha, D. and Pragathi, D. (2013). Optimization of Biomass Yield and Asiaticoside Accumulation in the Callus Cultures from the Leaves of Centella asiatica (L). Urban. World Journal of Pharmacy and Pharmaceutical Sciences, 2(6), 59665976.

Sankepally, S.S.R., Talluri, V.R. Arulmarianthan, J.P. and Bharat, S. (2016). Callus Induction and Regeneration Capabilities of Indica Rice Cultivars to Salt Stress. Journal of Biomolecular Research and Therapeutics, 5(1), $1000136 . \quad$ https:// doi.org/10.4172/2167-7956.1000136

Shahsavari, E., Maheran, A.A., Siti Nor Akmar, A. and Hanafi, M.M. (2010). The effect of plant growth regulators on optimization of tissue culture system in Malaysian upland rice. African Journal Biotechnology, 9, 2088-2094.

Shilpy, S., Arun, K., Vivek, R., Ashwini, K. and Sharma, V.R. (2018). In Vitro callus induction and plant regeneration in basmati rice (Oryza sativa L.) varieties. Journal of Pharmacognosy and Phytochemistry, SP5, 65-69.

Shukla, R., Dube, A. and Koshy, E. (2014). Production of high quality embryogenic callus of rice. International Quarterly Journal of Life Sciences, 9, 1077-1080

Suraiya, B.M. and Alina, W. (2018). Efficient Callus Induction and Regeneration in Selected Indica Rice. Agronomy, 8, 77 . https://doi.org/10.3390/ agronomy 8050077

Tang, N., Junheng, L.V., Junlei, Z., Ding, L. 
and Mengliang, C. (2017). Efficient ReDifferentiation of Rice (Oryza sativa L.) Callus Induced by Exogenous Hormones Indole-3-Butytric Acid and Thidiazuron in Tissue Culture. Journal of Biobased Materials and Bioenergy, 11(1), 8-13. https://doi.org/10.1166/jbmb.2017.1623

Trigiano, R.N. and Gray, D.J. (2005). Plant Development and Biotechnology, p. 358. New York, USA: CRC Press. https://doi.org/10.1201/9780203506561

Upadhyaya, G., Sen, M. and Roy, A. (2015). In vitro callus induction and plant regeneration of rice (Oryza sativa L.) var. "Sita", "Rupali" and "Swarna Masuri. Asian Journal of Plant Science and Research, 5(5), 24-27.

Vikrant, A. and Rashid, A. (2003). Somatic embryogenesis or shoot formation following high 2,4 -D pulse-treatment of mature embryos of Paspalum scrobiculatum L. Biologia Plantarum, 46, 297-300. https://doi.org/10.1023/A:1022875332607

Wanichananan, P., Teerakathiti, T., Roytrakul, S., Kirdmanee, C. and Peyachoknagul, S. (2010). A highly efficient method for Agrobacterium mediated transformation in elite rice varieties (Oryza sativa $\mathrm{L}$. spp. indica). African Journal of Biotechnology, 9, 5488-5495.

Zhao, W., Zheng, S. and Ling, H.Q. (2011). An efficient regeneration system and Agrobacterium-mediated transformation of Chinese upland rice cultivar Handao 297. Plant Cell, Tissue and Organ Culture, 106(3), 475-483. https://doi.org/10.1007/ s1 1240-011-9946-2

Zuraida A.R., Naziah B. and Zamri, Z. (2011). Efficient Plant Regeneration of Malaysian indica Rice MR 219 and 232 Via Somatic Embryogenesis System. Acta Physiologiae Plantarum, 33, 1913-1921. https://doi.org/10.1007/s11738-011-0739-3 